\title{
HVMANITAS
}

\section{Keats's sonnet on Chapman's translation of Homer: manuscript of early draft and initial publication}

\author{
Autor(es): $\quad$ Head, Brian Franklin \\ Publicado por: Imprensa da Universidade de Coimbra \\ URL \\ persistente: \\ URI:http://hdl.handle.net/10316.2/27434 \\ DOI: \\ DOI:http://dx.doi.org/10.14195/2183-1718_65_13 \\ Accessed : $\quad$ 26-Apr-2023 13:15:47
}

A navegação consulta e descarregamento dos títulos inseridos nas Bibliotecas Digitais UC Digitalis, UC Pombalina e UC Impactum, pressupõem a aceitação plena e sem reservas dos Termos e Condições de Uso destas Bibliotecas Digitais, disponíveis em https://digitalis.uc.pt/pt-pt/termos.

Conforme exposto nos referidos Termos e Condições de Uso, o descarregamento de títulos de acesso restrito requer uma licença válida de autorização devendo o utilizador aceder ao(s) documento(s) a partir de um endereço de IP da instituição detentora da supramencionada licença.

Ao utilizador é apenas permitido o descarregamento para uso pessoal, pelo que o emprego do(s) título(s) descarregado(s) para outro fim, designadamente comercial, carece de autorização do respetivo autor ou editor da obra.

$\mathrm{Na}$ medida em que todas as obras da UC Digitalis se encontram protegidas pelo Código do Direito de Autor e Direitos Conexos e demais legislação aplicável, toda a cópia, parcial ou total, deste documento, nos casos em que é legalmente admitida, deverá conter ou fazer-se acompanhar por este aviso.

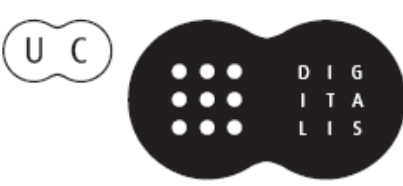


humanitas

Vol. LXV

2013

IMPRENSA DA UNIVERSIDADE DE COIMBRA

COIMBRA UNIVERSITY PRESS 


\title{
KEATS'S SONNET ON CHAPMAN'S TRANSLATION OF HOMER: MANUSCRIPT OF EARLY DRAFT AND INITIAL PUBLICATION*
}

\author{
Brian Franklin Head \\ Emeritus Center, University at Albany \\ Albany NY, USA
}

\section{Resumo}

Este estudo apresenta o mais antigo manuscrito conhecido do soneto de Keats sobre a tradução da Ilíada por Chapman (1611), com uma leitura comparada dos textos do manuscrito e da primeira publicação do soneto (1816), junto com comentários filológicos e literários.

Palavras chave: Keats, Chapman, Ilíada, família indo-europeia.

\begin{abstract}
This study presents the earliest known manuscript of Keats's sonnet to Chapman's translation of the Iliad (1611), in comparison with the first publication of the poem by Keats (1816). A comparative reading is provided, along with related philological and literary comments.
\end{abstract}

Key words: Keats, Chapman, Iliad, Indo-European.

* Artigo proposto para publicação em Maio e aceite em final do mesmo mês. 
The purpose of the present study is to present a copy of a manuscript of Keats's sonnet on Chapman's translation of Homer, in comparison with the text of the initial publication of this sonnet, along with some related philological and literary comments.

Keats's sonnet on Chapman's translation of the Iliad is well known, having frequently been included in collections of Keats's works. Later authors with references to Keats's sonnet include Edgar Allen Poe, Thomas Wolfe, F. Scott Fitzgerald, Vladimir Nabokov and P.G. Wodehouse.

Following partial translations from the Iliad in 1598 and 1608, Chapman released the complete twenty-four books under the title The Iliads of Homer in $1611 .{ }^{1}$

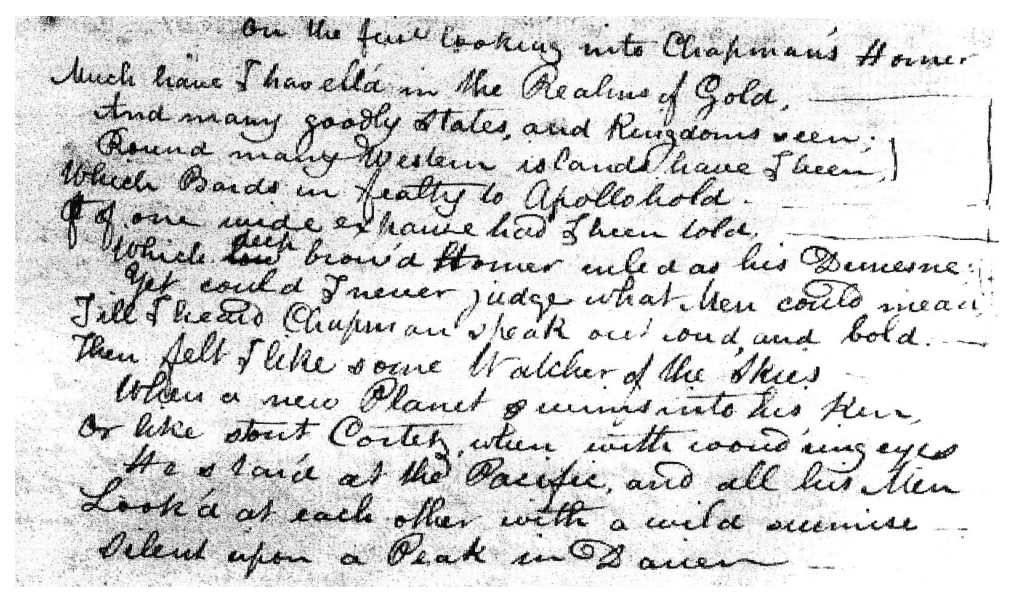

Prior to composing the sonnet (1816) on Chapman's work, Keats had completed a translation of The Aeneid, in 1811.

For purposes of reference, the manuscript reproduced here is identified as: Keats, John, 1795-1821. Much have I travell'd in the realms of gold. A. MS., early draft, MS Keats 2.4, Houghton Library, Harvard University, Cambridge MASS.

The following is a reading of the manuscript, presented beside the text of the first publication of the same sonnet, for purposes of comparison.

1 The complete title of the 1611 edition is The Iliads of Homer, Prince of Poets. Neuer before in any languag truely translated. With comment uppon some of his chiefe places; Done according to the Greeke. The current edition is Chapman's Homer, The Iliad. Edited with Introduction and Glossary, by Allardyce Nicoll, with a new preface by Garry Wills. Princeton NJ: Princeton University Press, 1998. 
On the first looking into Chapman's Homer

Much have I travell'd in the Realms of Gold, And many goodly States and Kingdoms seen; Round many Western islands have I been, Which Bards in fealty to Apollo hold. Oft of one wide expanse had I been told, Which deep brow'd Homer ruled as his Demesne:

Yet could I never judge what Men could mean, Till I heard Chapman speak out loud, and bold. Then felt I like some Watcher of the Skies When a new Planet swims into his Ken, Or like stout Cortez, when with wond'ring eyes He star'd at the Pacific, and all his Men Look'd at each other with a wild surmise Silent upon a Peak in Darien
On first looking into Chapman's Homer ${ }^{2}$ Much have I travell'd in the realms of Gold, And many goodly States and Kingdoms seen; Round many western islands have I been Which Bards in fealty to Apollo hold. But of one wide expanse had I been told, Which deep brow'd Homer ruled as his demesne;

Yet could I never judge what men could mean, Till I heard Chapman speak out loud and bold: Then felt I like some watcher of the skies When a new planet swims into his ken; Or like stout Cortez, when with eagle eyes He star'd at the Pacific, -- and all his men Look'd at each other with a wild surmise, -Silent, upon a peak in Darien.

Features of capitalization, punctuation and vocabulary in the early manuscript and in the Examiner:

Title Ms.: On the first..., Examiner: On first... (without «the»). 1.1. Ms.: Realms..., Examiner: realms... (without capitalization). 1.2. Ms.: States and Kingdoms..., Examiner: States and Kingdoms... (same $)^{3}$

1.3. Ms.: Western...been, Examiner: western (without capital)... been (no comma).

1.4. Ms.: Bards..., Examiner: Bards... (without capitalization in later publications).

1.5. Ms.: Oft..., Examiner But... (different wording).

1.6. Ms.: Demesne:, Examiner: demesne; (without capital, and with semi-colon instead of colon).

1.7. Ms.: Men, Examiner: men. (without capitalization).

1.8. Ms.: loud, ... bold. Examiner: loud (no comma)... bold: (colon, instead of period)

2 As published The Examiner, December 1, 1816, p. 762. For a more recent publication of this sonnet, see Keats, J. (1992), Poetical Works, Oxford University Press: 38.

3 Some of the later publications have one or both of these words beginning with a small letter. 
1.9. Ms. Watcher of the Skies. Examiner: watcher of the skies. (without capitals)

1.10. Ms.: Planet... Ken, Examiner: planet... ken; (without capitalization). 1.11. Ms.: wond'ring eyes. Examiner: eagle eyes. (different wording). 1.12. Ms.: Pacific, ... Men, Examiner: Pacific, -- ...men (with dash after Pacific, men not capitalized).

1.13. Ms.: surmise Examiner: surmise, -- (comma and dash after surmise).

1.14. Ms.: Silent ... Peak ... Darien, Examiner: Silent peak, Darien.

The following philological comments are made for the purpose of clarifying the lexical structure of the sonnet, in addition to indicating the nature of Keats's vocabulary. Line 1: realm, Middle English roialme, realme, Old French realme, French royaume «kingdom», from late Latin * rāgālimen, accusative of rāgālis «royal», from Indo-European *reg- «to move in a straight line» with derivatives meaning «to direct in a straight line», oldest form *hrế-. Lengthened-grade form *rēg- was Indo-European word for a tribal king, source of Old High German -rìh «king, ruler», suffix in personal names. Suffixed *rēg-en-: source of Sanskrit rājā, rājan- «king, rajah», rājni «queen,

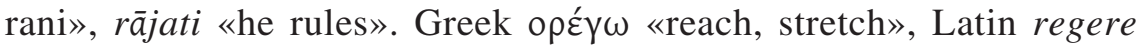
«direct, lead», Irish rigim «stretch out», Gothic uf-rakjan «stretch out». Lehmann (1986: R18) lists Sanskrit rāt, rāja, Latin rēx, Old Irish rī «king» from Proto-Indo-European *rēêg-s «ruler». (Watkins 2011: 72b, Pokorny 1. rề- 854. $)^{4}$

Line 2: goodly is the combination of good plus the suffix -ly, meaning «somewhat large, considerable», with good via Old English gōd, from Germanic *gōdaz, «fitting, suitable», allied to Old Slavonic god «fit season», Russian годный «fit, suitable» and Polish godny «worthy», from common

4 The principal source for identification of Indo-European roots is Watkins (2011), with additional information from Pokorny (1959) and from data from on-going Indo-European research on Proto-Indo-European Etyma (Pokorny Master PIE Etyma) at the Linguistics Research Center of the University of Texas at Austin. Skeat (1980) is a useful source for cognate forms in the Germanic languages and for description of words from Latin via Old French, Vasmer $(1958,1987)$ for related forms in the Slavic languages, Lehmann (1986) for Gothic and related words in other Indo-European languages, and Johnson (1755) for earlier meanings of English words. 
origin in the earlier Indo-European *ghedh- «to unite, join, fit» (Watkins 2011: 29a, Pokorny ghedh- 423.)

The derived form kingdom «country, state ruled by a king» is from Old English cyningdōm: king + dom, hence literally the «domain of a king». The base word king is from the Indo-European root *genэ-, also *gen-, «to give birth, beget, with derivatives referring to aspects and results of procreation and to familial and tribal groups»; oldest form * $\mathbf{g e n h}-$. The word king is from the zero-grade form * gṇ-. Related words in English include, among many others, gene and indigenous. Related forms in other languages include Anglo-Saxon cyning «king» (literally, a man of good birth), cyne- «royal», cyn «tribe, kin, race», Latin gignere (past participle genitus) «to beget» and gnāscī, nascī (gnātus, natus) «to be born», Greek үóvos «procreation» and үov'́ «seed, offspring», and Sanskrit janahv «offspring», jāta- «born», janate «he is born» (Watkins 27a, Pokorny 1. ĝ $e n-373$.

The ultimate source of the suffix -dom is from the Indo-European root *dhē- «to set, put» (contracted from earlier dheh-), origin of Old English $d \bar{\propto} d$ «doing, deed» via Germanic *dēdiz. Variant *dhō- is origin of current English «do» from Old English dōn «to do», Germanic *dōn. Suffixed o-grade form *dhō-mo- is origin «doom» from Old English dōm «judgement», while -dom is from Old English - dōm, abstract suffix indicating state, condition or power, also Old Norse -dōmr «condition» in compound hōrdōmr. Related forms in other branches of Indo-European include Russian дума «thought, council» and Ukranian дума «thought, narrative poem», both from a Germanic source akin to Gothic dōms «judgement». (Watkins 2011: 18a-b, Pokorny 2. dhā- 235.)

The word state comes via Old French estat from Latin statum, accusative of status «standing, condition», supine of stāre «to stand», Indo-European root *stā- «to stand», with derivatives meaning «place or thing that is standing», oldest form: *steh, colored to *stah, contracted to *stā-. Also origin of Avestan and Armenian stăya «stand, place», Latin sistō , stō «stand», Anglo-Saxon standan «stand», Old Irish tair- «stand», Old High German

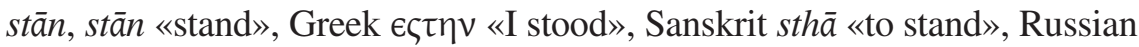
стоять «to stand», Lithuanian stóju «stand», Tocharian B ste «is». (For related words in English, see Watkins 2011: 86b-87b; Pokorny stā- 1004.)

Line 4: bard is from Welsh barrd and Gaelic Irish bard, origin of

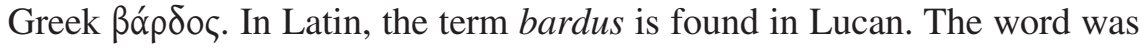
originally used in reference only to Celtic poets and, in lowland Scotland, to wandering minstrels; the meaning was later extended for general reference 
to poets. Although both the New English Dictionary (Oxford 1884) and the Oxford English Dictionary (Oxford 1971) indicate that the earliest documentation of the word is from the mid-fifteenth century, Bard had already become a surname by the end of the thirteenth century. Cf. Scottish surname Baird. The Indo-European root is * $\mathbf{g}^{\mathbf{w}} \mathbf{e r a}$ - «to favor». Celtic *bardo refers to a «praise poet», one who produced and bestowed praise poetry as gratification to his patron. (Watkins 2011: 35b, Pokorny 4. guer(z)- 478.)

Line 5: expanse is related to the Latin verb expandere, from pandere, pans- «to spread». The Indo-European root is *pet9- «to spread», also the origin of Old English foethm «fathom», from Germanic *fathmaz «length of two arms extended». There are numerous derivatives from Latin patāre «to be open» and pandere (past participle pāssus < * patto-) «to spread out», as well as from Greek $\pi \dot{\varepsilon} \tau \alpha \lambda$ ov, «thin plate», neuter of $\pi \dot{\varepsilon} \tau \alpha \lambda \circ$,

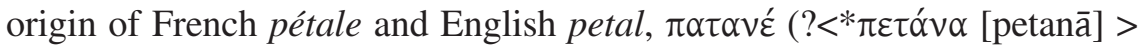
Latin patina) «platter» and $\pi \varepsilon ́ \tau \alpha \zeta \circ \varsigma$ «broad-brimmed hat». (Watkins 2011: 69b, Pokorny 2. pet-825.)

Line 5 begins with «Oft» in the manuscript, with «But» in the first published version. The former emphasizes the frequency of a certain special reference to Homer, the latter contrasts Homer's domain with that of other literary references in the sonnet.

Line 6: low brow'd changed to deep brow'd. The word 'low' has meanings similar to those of 'deep': «deep browed» (or «low browed») implies profound knowledge and intellectual powers. The term lowbrow (based on highbrow) in the sense of 'unsophisticated' or 'trivial', is documented beginning in the early 20th century. In general, «brow» refers to the ridge above the eyes, also to «contenence». The Indo-European root is *bhrū- «eyebrow», contracted from *bhruh, which yielded Middle English browe, from Old English $b r \bar{u}-$, via Germanic *bhrūs. Related forms include Icelandic brūn and, from other branches of the Indo-European family, Lithuanian bruwis, Russian бровь, Greek ó $\varphi$ ús, Persian abrū, Sanskrit bhrū. (Watkins 2011: 14a, Pokorny 1. bhrū- 172, 2. bhrū- 173.)

Line 6: demesne refers to «possession of own land». The term entered English in the fourteenth century, via Old French demeine «belonging to a lord», from Latin dominus «lord» (allied to verb domāre «to tame»), dominicus «pertaining to a lord», also the source of English domain, a more modern form, from 15th century French domaine through alteration of demeine 'demesne', source of English demesne, ultimately from Indo-European *dem- «house, household», with reflexes in several branches, such as Greek 


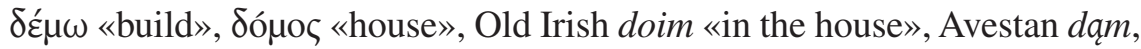
dąmi «in the house», Armenian tun «house», Tocharian A tam- «produce, to be born», Tocharian B tem- «produce, to be born». (Watkins 2011: 16b, Pokorny dem-, demo- 198). Cf. Johnson 1755 q.v.

Line 7: mean (in both early draft of ms. and in the earliest printed version of the sonnet, The Examiner, December 1, 1816) comes from Middle English menen, Old English mēnan «to intend», Old Irish mían, Brittonic mwyn, Old High German meinen «to think», meina «thought» (related to minni «memory»), Germanic *mainjan, Dutch meenen, Danish mene, Swedish mena, as well as slavic meinō, Old Church Slavonic mĕnjo, mĕniti, Russian мненйе «орinion», all utimately from Indo-European *mei-no- «opinion, intention». (Watkins 2011: 54b-55a, Pokorny mei-no- 714.)

A later version (1992, see n. 2, supra) has a different text for this line, ending with serene, from Latin serēnus, via French, with the derivatives serenity, French sérénité and Latin serēnitās each used as honorific forms in certain titles. The use of serene («Yet did I never breathe its pure serene») is in accord with the reference to the Pacific, in the second and final simile in the sestet, in comparison with the experience of reading Chapman's translation of Homer, «till I heard Chapman speak out loud and bold». Both the early manuscript and the first printing indicate the unique nature of the experience («Yet could I never...»). The Indo-European root is *ksero- «dry»,

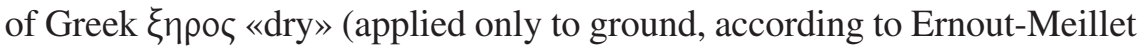
1939: 928), Latin serenus, and Tocharian A ksär «morning», among others. (Watkins 2011: 46a, Pokorny ksĕ-ro- 625.)

Line 10: planet is from Middle English planete < Old French planete

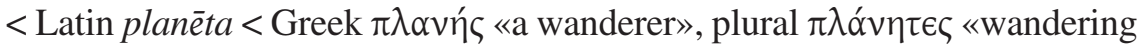
stars, planets», from Indo-European root *pels- «flat; to spread», also ultimate origin of поле «field» in Russian, Ukranian, and Old Russian, поле, with a cognate form in Old Slavonic; Bulgarian, поле́; Serbo-Croatian, поље; Slovenian, poljê; Polish, Czech and Slovakian, pole; in Upper Sorbian, polo; Lower Sorbian, pólo; and Polabian (now extinct), pülü (Vasmer 1987: III, 307), in addition to other related words in Slavic languages, such as polak (in reference to Polish people) and polka (a Polish dance, originally only in reference to a Polish woman). (Watkins 2011: 66b, Pokorny pela- 805.)

Line 10: ken, meaning «can» and «know» is from Anglo-Saxon cennan. Cognate forms are well attested in the Germanic languages: German kennen, können, Dutch kennen, Old Norse kenna, Gothic kunnan «to know, recognize» and kannjan «to make known». The root is from Indo-European 
*gn̄o- «ken, know, recognize» (oldest form * $\mathbf{g} n e h-$ altered to *gnōh-, contracted to * $\mathbf{g} \mathbf{n} \overline{\mathbf{o}}-$ ), also origin of Latin gnārus «one who knows» (with numerous derivations and compounds) and its antonym ignārus, as well words in other branches of Indo-European: Classical Greek: $\gamma \nu \omega \varsigma$ - root of

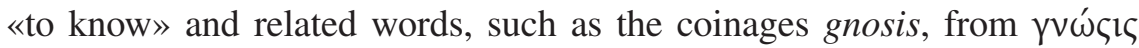
in the sixteenth century, and agnostic, based on ó $\gamma v \omega \varsigma \tau$ s (suggested in Acts xvii: 23), by Huxley in 1869; Avestan zānāiti «know» and zainti «knowledge»; Old Irish ad-gnimin «recognize»; Lithuanian žinóti «know», Old Prussian ersinnat «recognize», Armenian caneay «I Know» and an-can

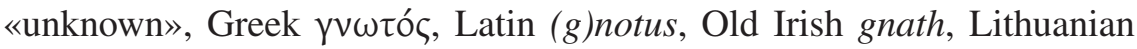
pa-žintas «known», Old Slavonic znati, Russian знать «know», Albanian $n j o h$ «know», Tocharian A and B knā- «know, recognize». (Lehmann 1986: K38, Watkins 2011: 33b, Pokorny 2. ĝen-, ĝenə-, ĝne-, ĝnō-, 376.)

Line 11: stout, Middle English stout, Old French estout «stout, bold», related to Anglo-Saxon and Low German stolt, with the same meanings, is ultimately from the Indo-European root *stel- «to put, stand», with variant forms giving origin to diverse words, such as Old English stille «quiet», current English Apostle, stallion, stolid. The modern meanings of stout include «determined, bold, brave» and «strong, sturdy». Other words from the same Indo-European root include, among others, Greek $\varsigma \tau \eta \dot{\lambda} \lambda \eta$ «pillar»,

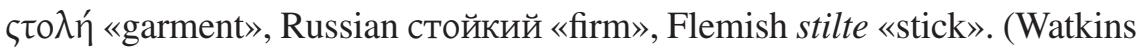
2011: 88a-b, Pokorny 3. stel- 1019. See also Skeat 1980: 522.)

Line 15: wild, meaning here «unrestrained, frenzied, full of intense emotion, bewildered», is ultimately from the Indo-European root *welt«woods, wild», which yielded forms such as Old English weald, wald, from Germanic *walthuz; wild from Old English wilde, wild, derived from Germanic *wilthja-. Cognate words in other Germanic languages include Dutch wild, Icelandic villr, Danish and Swedish vild, German wild, Gothic wiltheis. (Watkins 2011: 101a, Pokorny 4. ǔel-1139.)

Line 15: surmise, meaning «guess or notion based on intuition or limited information», is based on mittere «to let go, send off, throw», of uncertain origin, with the likely oldest form being *smittere, as in the archaic spelling cosmittere, of the Classical Latin compound committere «to bring together». (Watkins 2011: 57b, Pokorny *smeit-968.) The English verb surmise comes from Latin mittere via Old French surmise, feminine singular of the past participle of surmettre. The original sense in English is that of supposing or conjecturing, to which the meaning of Keats's phrase wild surmise clearly indicates. 
In terms of the use of punctuation and capitalization, there is close similarity between the features of the early manuscript shown above and those of the version of the sonnet first published in The Examiner on December 1, 1816. ${ }^{5}$ Most of the capital letters of the manuscript are preserved in the initial publication of the sonnet. The use of capitals in the manuscript is more extensive, including words that take the place of proper nouns, as well as some employed for emphasis. The punctuation is similar, with few differences. Both versions divide the octave into just two sentences, of four lines each, and both treat the sestet as a single sentence. It can be noted, however, that later publications have more differences, in relation to the texts considered here, with regard to the use of both punctuation and capitalization, with the later publications tending to be increasingly conservative with regard to contemporary pedagogical norms (hence, reflecting to a lesser degree the features of earlier versions). ${ }^{6}$

Keats's generation was familiar with the translations by John Dryden and Alexander Pope, in blank verse or heroic couplets, rendering Homer in a way similar to Virgil.

From the content of the sonnet, it is evident that Keats was profoundly impressed by Chapman's rendition. Keats had a special affinity with Chapman: both possessed good knowledge of classical culture, both were poets and Keats also translated a classical epic poem.

Formally, Keats's poetic tribute to Chapman is a sonnet in the style of Petrarch, consisting of an octave and a sestet, in iambic pentameter. The meanings of the parts are closely interrelated. That the manuscript is a draft

5 The website http://spenserians.cath.vt.edu/TextRecord.php?action=GET\&txtsid=36006 presents a version of the text as a copy of «On first looking into Chapman's Homer», as published in The Examiner (1 December 1816) 762. It is not, however, a faithful copy of the original publication, for, unlike the version published in The Examiner, it shows both of the names Chapmen and Cortez completely in capital letters: CHAPMAN... CORTEZ. There is no apparent justification for this change.

6 To the extent that they represent interference with the poet's intended forms and meanings, such versions must be considered distortive. Without additional specific information, one can only speculate with regard to the causes of such textual interference, which seems to be the result of greater concern for normative grammatical features of common usage than for the special aspects of poetic discourse (such as linking and emphasis) in accordance with the poet's own vision of his topic. One can imagine the distortions that would result from the use of normative principles by an overly zealous and disoriented editor for «correcting» the lack of capitalization in the poetry of e e cummings (Edward Estlin Cummings) or the lack of punctuation in the prose of Portuguese Nobel Prize winner José Saramago. 
(rather than merely a copy) is indicated both by the change in the text (line 6) and by marks connecting paired lines.

It is clear the «realms of gold» refers to literary riches, as evidenced by the successive references, in the first eight lines, to the Aegean islands, to Apollo (god of poetry, born at the sacred island of Delos, in the Aegean), to Homer, then to Chapman, preceded by «Yet could I never know what Men could mean», which calls attention to the value of literary translation in making works available to those who otherwise would not have access to them, and especially to the value of quality in translation. The sestet concerns the magnitude of the experience of the first reading of Chapman's translation, through two comparisons: first with taking knowledge of a new planet, then with an initial sighting of the Pacific.

Keats's generation knew of the discovery of Uranus, the first planet to become known modern times (not known in antiquity). Uranus (named after the Greek god ruler of the heavens) had been found fortuitously by Herschel in 1781. The phrase «swims into his ken» suggests the mode of the discovery (-- contrary to the case of Neptune, to be discovered more than half a century later, through mathematical calculations, in 1846). Literary connections with the planet Uranus include the names of its seventeen satellites, all for characters in Shakespearean plays.

The second and final comparison is with the initial viewing of the Pacific Ocean by Cortez with «eagle eyes» (as shown in Titian's painting of this subject), changed from «wond'ring eyes», hence denoting close attention, in addition to the wonderment indicated by «wild surmise» and «silent»), while «all his men look'd at each other in wild surmise». The two comparisons show the vastness of the discovery and the nature of its impression.

There are several links between words of like meaning, such as «Realms» (line 1), «Kingdoms» (line 2) and «Demesne» [=domain] (1. 6), between the reference to the Aegean Islands (1. 3), suggesting water, extended through the use of «swim» (1. 10), culminating in the reference to the awe-inspiring Pacific Ocean, and between the vastness suggested by the use of wide expanse (1. 5), the reference to a planet (1. 10), then the reference to the Pacific (1. 12). Such connections contribute to the emphasis and unity of the poetic composition. The climactic impression made by the total imagery of these comparisons is one of awe, caused by reading Chapman's Homer.

Historically, the reference to Cortez viewing the Pacific from the Darién province in Panama is an error: it was Balboa, not Cortez, who viewed 
the Pacific Ocean from Panama. It has been suggested that Keats did not change the reference to Balboa, because doing so would have added another syllable. Such a motive seems hardly likely: Keats gave ample evidence of poetic skill in more than fifty compositions. The differences both within the manuscript of the «early draft» reproduced here (line 6) and between it and the later publication (lines 7 and 11) show that it would not have been difficult for Keats to make additional changes required by alteration of the reference. The name of Cortez, who conquered Mexico and served as its governor, has different connotations and imagery from that of Balboa. Moreover, it is Cortez, not Balboa, who was immortalized in a portrait by Titian. Of course, many early explorers and conquistadores viewed the Pacific, as did Cortez, one of the most famous leaders of sixteenth century European expansion.

The final comparison in the sestet, with «stout Cortez», recalls the attributes determined, bold and strong, qualities also to be associated, as mental courage and artistic prowess, with both «deep-browed Homer» and Chapman, the principal English translator of The Iliad.

\section{Bibliography}

Ernout, A. et A. Meillet (1939), Dictionnaire Étymologique de la Langue Latine. Histoire des mots. Paris: Librairie Klincksieck.

Johnson, Samuel (1755), A dictionary of the English language: in which the words are deduced from their originals, and illustrated in their different significations by examples from the best writers. To which are prefixed, a history of the language, and an English grammar. London, Printed by W. Strahan. (Facsimile edition: New York: AMS Press, 1967.)

Keats, John. Manuscript: Much have I travell'd in the realms of gold. A. MS., early draft, MS Keats 2.4. Houghton Library, Harvard University, Cambridge MA.

Keats, John. “On first looking into Chapman's Homer", The Examiner, 1 December 1816: 762 .

Keats, John (1992), Poetical Works. Oxford: University Press.

Lehmann, Winfred (1986), A Gothic Etymological Dictionary. Based on the third edition of Vergleichendes Wörterbuch der Gotischen Sprache by Sigmund Feist. Leiden: E. J. Brill.

Pokorny, Jules (1959). Indogermanisches etymologisches Wörterbuch. Bern, München: Francke Verlag. 
Pokorny Master Proto-Indo-European Etyma. Information available on the Internet: www.utexas.edu/cola/centers/lrc/ielex/PokornyMaster-X.html

Skeat, Walter W. (1980), A Concise Etymological Dictionary of the English Language. New York: G. P. Putman's Sons.

Vasmer, Max. Russisches etymologisches Wörterbuch. Heidelberg: Carl Winter 1958. Russian edition: Макс Фасмер, Этимологический Словарь Русского Языка.4 t. Москва: Прогресс, 1987.

Watkins, Calvert (2011, 3rd. ed.), The American Heritage Dictionary of IndoEuropean Roots. Boston and New York: Houghton, Mifflin, Harcourt. 